\title{
Spatial distribution of macrofauna within a sandy beach on the Caribbean coast of Costa Rica
}

\author{
Jeffrey A. Sibaja-Cordero ${ }^{1,2}$ \\ 1. Centro de Investigación en Ciencias del Mar y Limnología (CIMAR), Ciudad de la Investigación, Universidad de \\ Costa Rica, San Pedro, San José 11501-2060, Costa Rica, jeffro@costarricense.cr \\ 2. Escuela de Biología, Universidad de Costa Rica, San José 11501-2060, Costa Rica.
}

Received 16-I-2017. Corrected 15-XI-2017. Accepted 03-I-2018.

\begin{abstract}
Knowing the spatial pattern and densities of individuals in a population is basic to understand ecology such as their response to environmental gradients. The main goal of the present study is to describe the abundances and distribution of the benthic fauna in the lower intertidal level of a sandy beach at Pacuare Reserve, Caribbean Coast, Costa Rica. The count data of five taxa (in 29 cores) was analyzed to determine their spatial distribution. Two species of polychaetes were found: the first, Scolelepis (Scolelepis) squamata (O. F. Mueller, 1806) was common in the center of the beach in an aggregated pattern. The second, Pisionidens indica (Aiyar \& Alikunhi, 1940) was present in low densities with a random distribution pattern. Moreover, two isopods were found: Excirolana braziliensis Richardson, 1912 was randomly distributed along the beach while Ancinus brasiliensis Lemos de Castro, 1959 appeared only in two stations. A meiofaunal nemertean attached to grains of sand was the most common organism in the intertidal zone, showing a clumped pattern. The patches of abundance within the beach could be due to a morphologic change that imposes the influence of the strong surf conditions. Moreover, food resource distribution, niche partitioning or competition within the same tide level could influence the different patterns of distribution found in the sediment among the species. In these unstable sediments, the fauna was limited to few opportunist taxa well adapted to withstand mechanical disturbances. Rev. Biol. Trop. 66(Suppl. 1): S176-S186. Epub 2018 April 01.
\end{abstract}

Key words: Soft bottom, Count data analysis, Polychaetes, Peracarida, Poisson, Negative binomial.

Soft-bottom marine habitats contain infaunal organisms living between the sediment grains. The first step in the description of the structure of seemingly homogeneous system is the analysis of the abundance patterns of each taxon. Knowing the spatial pattern from the count data of a population can aid in the understanding of other aspects of their ecology such as recruitment, and use of food resources. Also, it is relevant to understand their demography strategies in the benthic system and their responses to environmental gradients or disturbance impacts (Thrush, 1991; Krebs, 1999). For example, patchy distribution of adults of benthic infauna may be associated with factors such as settling preferences of larvae in marine sediments and survival of individuals after predation or other disturbances (Thrush, 1991). Differences in distribution patterns in the sediment may be attributed to patchy distribution of food resources or environmental gradients. Gonçalves, et al. (2009), for example, found that peracarids moved between sectors of the beach to avoid desiccation stress or high temperatures. Other explanations for distribution patterns are niche partitioning by age class or competition among species (Glynn, Dexter, \& Bowman, 1975).

Most tropical benthic marine research has been carried out in subtidal soft-bottom habitats rather than intertidal habitats (Alongi, 1990; Sibaja-Cordero et al., 2016). In Costa Rica, for example, the subtidal assemblages have been well studied in the Pacific coast 
including ecological studies of macrofaunal and meiofaunal communities (Guzmán, Obando, \& Cortés, 1987; Maurer, Vargas, \& Dean, 1988). The subtidal macrofauna of the Golfo de Nicoya shows a temporal dynamic in their abundance and their spatial distribution due to natural or anthropogenic changes in the environment (Maurer, \& Vargas 1984; Rostad, \& Hansen, 2001). Also the benthic subtidal macrofauna of Golfo Dulce varies in species abundances in the deeper zone of this fjord-like embayment due to decreases in oxygen levels with depth (Nichols-Driscoll, 1976; León, \& Vargas, 1998). Most of these subtidal systems reported higher abundances of macrofauna than others sites in the Tropical Eastern Pacific, as the case of Isla del Coco and Gulf of Nicoya (Sibaja-Cordero et al., 2016). Additionally, tidal flats associated with estuarine systems in Costa Rica had higher abundances of macrofuana and meiofauna in areas of reduced desiccation and higher food input to the sediments (De la Cruz, \& Vargas, 1987; Vargas, 1988a, 1988b; Dittmann, \& Vargas, 2001). For example, Vargas-Zamora, Sibaja-Cordero, Dean, \& Solano-Ulate (2015) showed an aggregate pattern of abundance for three species of polychaetes with different feeding habits in Punta Morales, on the Pacific coast of Costa Rica.

In contrast, sand beaches are frequently considered devoid of fauna by people unfamiliar with this habitat. But several descriptive studies indicate higher abundances, mainly in dissipative beaches (flat beach with a wide surf zone) with a wide tidal range $(\sim 3 \mathrm{~m})$ (Defeo, \& McLachlan, 2005). The beaches of the Caribbean Sea have a narrow tidal range since the water does not respond strongly to tidal forces due to its size and geography. As a result, the intertidal zone is about $1.2 \mathrm{~m}$ on the sandy beaches of the Central America Caribbean. Only two studies with macrofauna (with emphasis in vertical distribution) have been carried out on sandy beaches in the South Caribbean of Central America (Dexter, 1974, 1979). Moreover, Caribbean beaches of Costa Rica are most exposed to wave influence and in many cases are reflective beaches (Salazar, Lizano, \& Alfaro, 2004). Such beaches with a high intertidal slope usually have low abundances and low diversity of fauna (Defeo, \& McLachlan, 2005).

The knowledge of the basic ecology of intertidal macrofauna and the impact of highly dynamic beaches on the spatial distribution and diversity of the rest of the Caribbean coast of Central America is scarce. The present descriptive study has the objective to model the horizontal distribution patterns of abundances of intertidal macrofauna in the sandy beach intertidal in the north Caribbean of Costa Rica.

\section{MATERIAL AND METHODS}

Study site: The study was carried out on the North Caribbean coast of Costa Rica. In this region the sediments are mainly of terrigenous origin with a low calcium component (Salazar et al., 2004). This is in contrast with other beaches in the south Caribbean region of Costa Rica and Panama where sediments are mainly carbonated (Dexter, 1974; Alongi, 1989; Salazar et al., 2004). The intertidal zone on the Caribbean side of Costa Rica ranges from 1 to $1.5 \mathrm{~m}$ (Bakus, 1968).

Mondonguillo beach is located between the mouths of the Pacuare river and Matina river (south limit: $10^{\circ} 7^{\prime} 8.89^{\prime \prime} \mathrm{N}-83^{\circ} 11^{\prime} 33.56^{\prime \prime} \mathrm{W}$, and north limit: $10^{\circ} 13^{\prime} 13.50^{\prime \prime} \mathrm{N}-83^{\circ} 16^{\prime} 26.72^{\prime \prime} \mathrm{W}$ ). The zone is not urbanized, with dense terrestrial vegetation (Fig. 1). Mondonguillo is an exposed sandy beach and it has been marked with stakes located each $100 \mathrm{~m}$ and numerated from 0 to 57 as part of a conservation project on the sea turtles of Pacuare Reserve. These marks were used as guides to sampling in the present study from $10^{\circ} 10^{\prime} 2.50^{\prime \prime} \mathrm{N}-83^{\circ} 14^{\prime} 0.22^{\prime \prime} \mathrm{W}$ to $10^{\circ} 12^{\prime} 33.16^{\prime \prime} \mathrm{N}-83^{\circ} 15^{\prime} 54.46^{\prime \prime} \mathrm{W}$ (Fig. 1). The beach berm is about $50 \mathrm{~m}$ width and the intertidal is about 1-2 m width (Fig. 1). The granulometry of sediment samples taken during the study between sectors 30 to 54 is presented. During the period of study sectors 9-19 and 43-49 exhibited the erosion of the beach by waves (Fig. 1). 


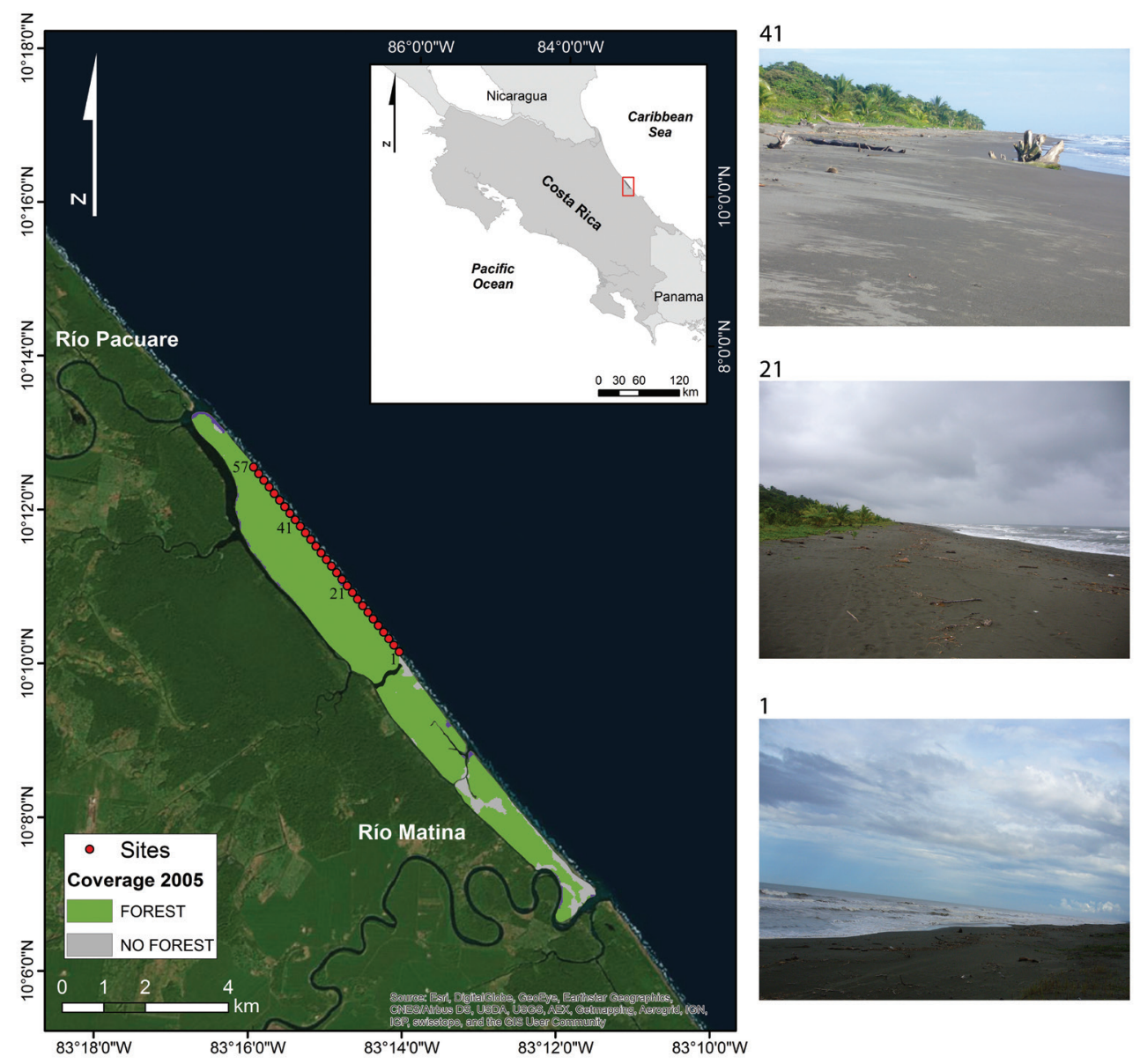

Fig. 1. Transect for sampling macrofauna in Mondonguillo beach. Red circles are sites from 1 to 57 . Made by Catalina Benavides-Varela, SIGMAR-CIMAR. Pictures show the beach berm at site 1 and 21 with a reduced intertidal, and the view from site 41 that shows the erosion of the beach by waves in September 2006.

Spatial pattern: Twenty nine samples of sediments were collected (September 2006) every $200 \mathrm{~m}$ along a parallel transect at the low spring tide level. Samples were taken using a cylindrical core of $18.86 \mathrm{~cm}^{2}$ to a depth of 15 $\mathrm{cm}$ into the sediment. Buffered formalin (5\% $\mathrm{v} / \mathrm{v}$ ) in sea water stained with Rose Bengal was used to preserve the samples (Vargas, 1987). Samples were washed with fresh water through a $500 \mu \mathrm{m}$ mesh sieve to retain the macrofauna and the organisms were extracted, identified and counted with the help of a dissecting microscope (Vargas, 1987).

The Bray-Curtis index was used to measure the similarity in the distribution of the taxa along the intertidal zone. The spatial patterns of distribution were analyzed using $\mathrm{R}$ ( $\mathrm{R}$ Core Team, 2014) (Appendix 1-3). The sequences of commands in $\mathrm{R}$ followed the steps in Krebs (1999) and are applicable for other count data in benthic ecology. The index of dispersion (ID) was based on the variance/mean of each taxa and the respective chi-squared values $\left(\chi^{2}\right)$ were used to test the null hypothesis of a random pattern $(I D=1)$. The count data of each taxon was checked for fit to a known probability distribution according to the steps in Krebs (1999) and Crawley (2007): Poisson distribution for random pattern (ID = 1), negative binomial distribution for aggregated 
pattern (ID > 1), and binomial distribution for uniform pattern $($ ID $<1)$. Observed frequencies by counts and the expected values based on these distributions for each taxon were compared with a G Goodness of Fit Test (Krebs, 1999). To meet the assumption that all expected values are greater than 1 the observations with expected values $<1$ were pooled (Krebs, 1999). The $G$ test was adjusted using the Williams correction for continuity of small samples ( $\mathrm{n}<$ 200) (Krebs, 1999). The degree of freedom of the $\mathrm{G}$ test for a Poisson distribution is the number of frequency classes used minus $2(\mathrm{~N}$ and $\lambda$, where $\mathrm{N}=$ total abundance and $\lambda=$ mean) and for a binomial distribution is the number of frequency classes used minus $3(\mathrm{~N}, \mathrm{k}$ and $\mathrm{p}$, where $\mathrm{k}$ is the maximum number of individuals can be found in a sampling unit, and $p$ the probability of an event x occurs). Finally, for a negative binomial distribution, the degree of freedom is the number of frequency classes used minus $3(\mathrm{~N}, \mathrm{k}$ and $\mathrm{p}$, where $\mathrm{k}$ is negativebinomial exponent and $\mathrm{k}^{*} \mathrm{p}=$ mean) $(\mathrm{Krebs}$, 1999; Crawley, 2007). The commands in $\mathrm{R}$ for random, clumped and uniformed patterns are presented in Appendix 1-3, respectively. The data matrix can be downloaded from http:// www.kerwa.ucr.ac.cr/handle/10669/29428

\section{RESULTS}

Based in the granulometric analysis the beach is composed of fine sands. Sand fractions $>500 \mu \mathrm{m}$ were only $1 \%$, and very fine fractions $(<63 \mu \mathrm{m})$ were between 2 to $7 \%$. A slightly pattern of increase in grain size of 125 to $250 \mu \mathrm{m}$ was observed from the center of the transect to the mouth of the Pacuare river (Fig. 3).

A total of 198 individuals distributed in five taxa were found in 29 corers, two species isopods, one nemertean species and two species of polychaetes (Fig. 2). The nondetermined nemertean was the most common taxon, followed by the annelid Scolelepis (Scolelepis) squamata (O. F. Mueller, 1806) (Spionidae). An isopod Excirolana braziliensis Richardson, 1912 was very abundant
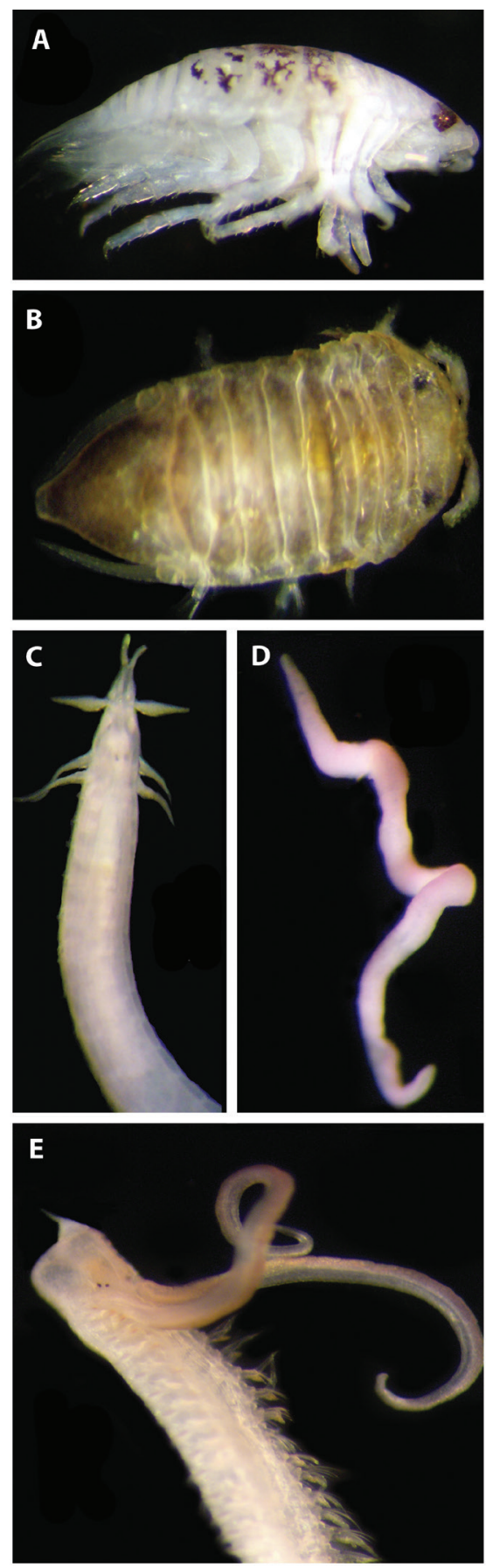

Fig. 2. Invertebrates of the sediment in the intertidal of Mondonguillo Beach, Pacuare Reserve, Limón. 2006. $\mathrm{A}=$ Excirolana braziliensis (Isopoda), $\mathrm{B}=$ Ancinus brasiliensis (Isopoda), $\mathrm{C}=$ Pisionidens indica (Pisionidae), $\mathrm{D}=$ Nemertea $\mathrm{sp}$. indet. and $\mathrm{E}=$ Scolelepis squamata (Spionidae). 

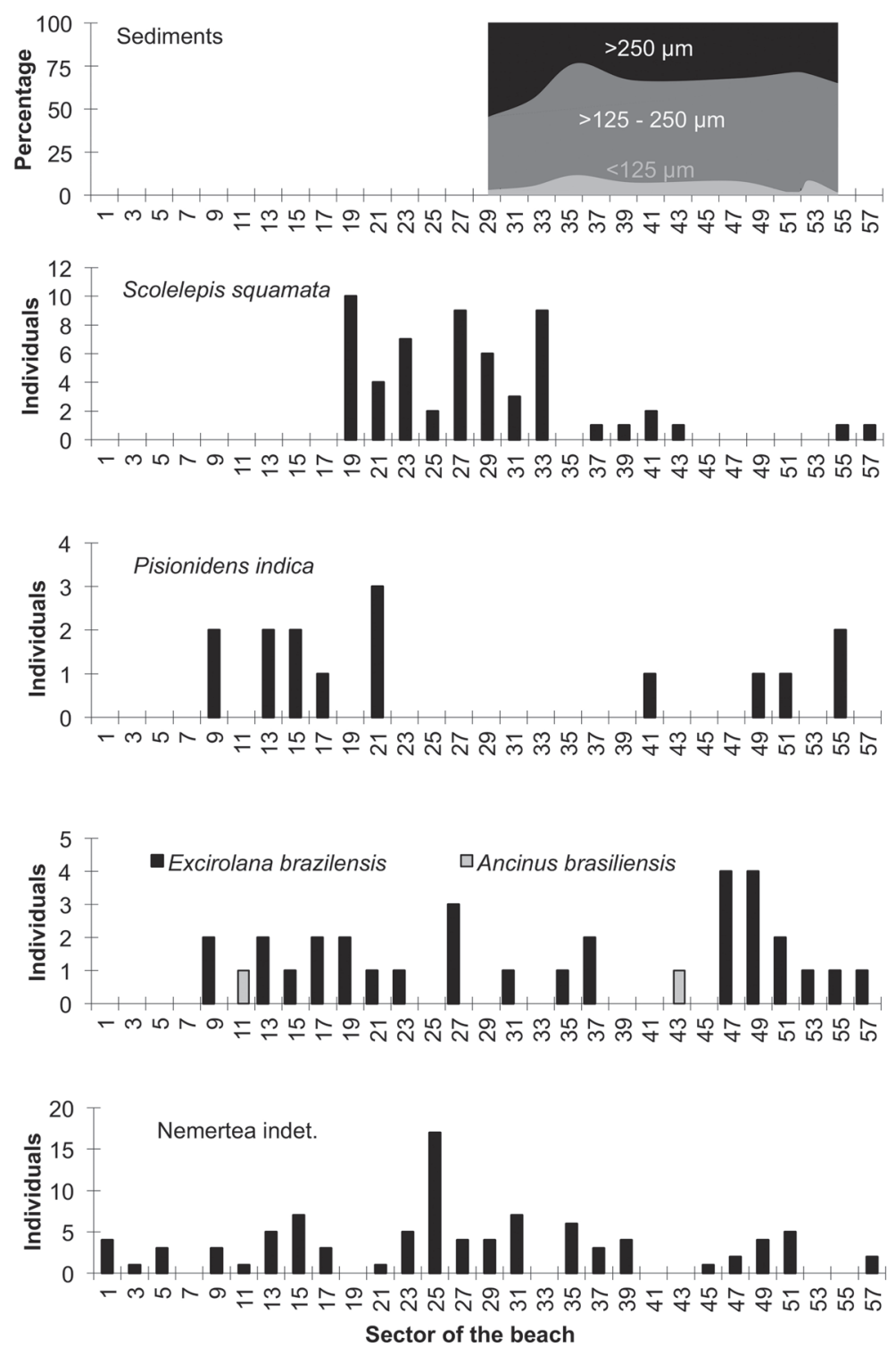

Fig. 3. Sediment fractions distribution for sector 30 to 54 , and abundance of the taxa along the $5.8 \mathrm{~km}$ in the Mondonguillo beach to low tide level. Costa Rica, September 2006. The number in x axis are the sector of the beach of this reserve.

in Mondonguillo beach, while Pisionidens indica (Aiyar \& Alikunhi, 1940) (Pisionidae) was lowest in densities (Table 1). The isopod Ancinus brasiliensis Lemos de Castro, 1959 occurred only in two sectors (11 and 43).

Species that presented the most similar distribution (44\% based in Bray-Curtis index) were E. braziliensis with $P$. indica. This pattern is most attributable to the amount of individuals as these species only shared eight stations in their distribution (Fig. 3; Table 1). The pattern of similarity between E. braziliensis and the nemertean (41\%) is most attributable to the coincidence of these species in 14 stations and their absence in three stations. The distribution of $S$. squamata was lower in 
TABLE 1

Similarity (Bray-Curtis index) between abundance profiles of each taxon found along the $5.7 \mathrm{~km}$ of the Mondonguillo beach, Costa Rica. The lower off-diagonal elements refer to the Bray-Curtis index and upper off-diagonal elements correspond to the number of matching stations between each pair of taxa.

\begin{tabular}{lccccc}
\multicolumn{1}{c}{ Taxon } & $\begin{array}{c}\text { Ancinus } \\
\text { brasiliensis }\end{array}$ & $\begin{array}{c}\text { Excirolana } \\
\text { braziliensis }\end{array}$ & $\begin{array}{c}\text { Nemertea sp. } \\
\text { indet. }\end{array}$ & $\begin{array}{c}\text { Pisionidens } \\
\text { indica }\end{array}$ & $\begin{array}{c}\text { Scolelepis } \\
\text { squamata }\end{array}$ \\
$\begin{array}{l}\text { Ancinus brasiliensis } \\
\text { Excirolana braziliensis }\end{array}$ & 0.0 & 0 & 1 & 0 & 1 \\
Nemertea sp. indet. & 0.02 & 0.41 & 14 & 8 & 8 \\
Pisionidens indica & 0.0 & 0.44 & 0.19 & 7 & 9 \\
Scolelepis squamata & 0.03 & 0.25 & 0.30 & 0.14 & 3 \\
\hline
\end{tabular}

TABLE 2

Mean and variance by core $\left(18.86 \mathrm{~cm}^{2}\right)$ and type of spatial distribution of each taxa at low tidal level of Mondonguillo beach, Limón, Caribbean coast, Costa Rica. September 2006.

\begin{tabular}{lccc}
\multicolumn{1}{c}{ Taxon } & Mean & Variance & Spatial distribution \\
Isopods & 1.14 & 1.34 & random \\
Pisionidens indica & 0.52 & 0.76 & random \\
Scolelepis squamata & 1.96 & 9.75 & aggregated \\
Nemertea sp. indet. & 3.17 & 11.93 & aggregated \\
Total abundance & 6.79 & 21.74 & aggregated \\
Species richness & 2.20 & 0.88 & uniform \\
\hline
\end{tabular}

similarity $(<30 \%)$ to that of the nemertean and the isopod E. braziliensis (Fig. 3; Table 1). The two species of annelids only co-occurred in three stations resulting in a low similarity in their distribution (Fig. 3; Table 1).

The isopods E. braziliensis showed a random pattern (ID $=1.18 ; \chi^{2}=37.29$; d.f. $=28$; $\chi^{2} \alpha(0.975)=15.31 ; \chi^{2} \alpha(0.025)=44.46$; Table 2) described by the Poisson distribution (Fig. $4 \mathrm{~A} ; \mathrm{G}$ test $=0.15 ;$ d.f. $=2 ; \mathrm{p}=0.927$ ). The probability of having a count of one individual was 0.365 (Fig. 4A). The polychete $P$. indica had a random distribution (ID $=1.47$; $\chi^{2}=41.07 ;$ d.f. $=28 ; \chi^{2} \alpha(0.975)=15.31$; $\chi^{2} \alpha(0.025)=44.46$; Table 2$)$, but their counts do not fit the Poisson distribution (Fig. 4B; G test $=5.20$; d.f. $=2 ; \mathrm{p}=0.022$ ). Additionally, this worm was absent from sectors 23 to 39 (Fig. 3).

The worm $S$. squamata had an aggregated distribution (ID $=4.96 ; \chi_{2}^{2}=138.88$; d.f. $=$ $\left.28 ; \chi^{2} \alpha(0.975)=15.31 ; \chi^{2} \alpha(0.025)=44.46\right)$ forming a patch between sectors 19 to 43 (Fig. 3). The negative binomial distribution adequately described the clumped pattern of
S. squamata (Fig. 4C; G test $=3.02$; d.f. $=3$; $p$ $=0.389$ ). The approximate negative-binomial exponent $(\mathrm{k})$ was 0.496 and the maximum likelihood estimate for $k$ was 0.413 , which indicating a strongly clumped pattern.

Similarly, the nemertean species also had an aggregated distribution (ID $=3.76$; $\chi_{2}^{2}=105.33$; d.f. $=28 ; \chi^{2} \alpha(0.975)=15.31$; $\left.\chi^{2} \alpha(0.025)=44.46\right)$ due to its great variance in abundance between stations (Fig. 3). Nemertean distribution along Mondonguillo beach fits the negative binomial distribution (Fig. 4D; G test $=7.07$; d.f. $=6 ; p=0.314$ ). The count data presented an approximate negative-binomial exponent $(k)$ of 1.14 and the maximum likelihood estimate for $k$ was 1.22 (Fig. 4D). The total fauna exhibits a clumped pattern (ID $=3.20 ; \chi^{2}=89.61 ;$ d.f. $=28 ; \chi^{2} \alpha(0.975)$ $\left.=15.31 ; \chi^{2} \alpha(0.025)=44.46\right)$ following the negative binomial distribution (Fig. 4E; G test $=6.56$; d.f. $=9 ; \mathrm{p}=0.682$ ) with a maximum likelihood estimate for $k$ of 2.71 .

Finally, the overall taxa followed a uniform pattern along the beach (ID $=0.40$; $\chi^{2}=11.22 ;$ d.f. $=28 ; \chi^{2} \alpha(0.975)=15.31$; 
A

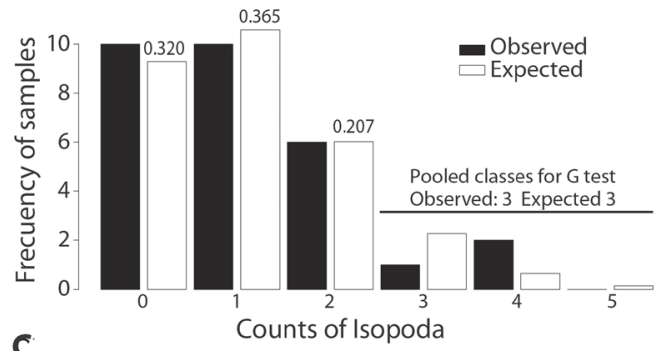

C

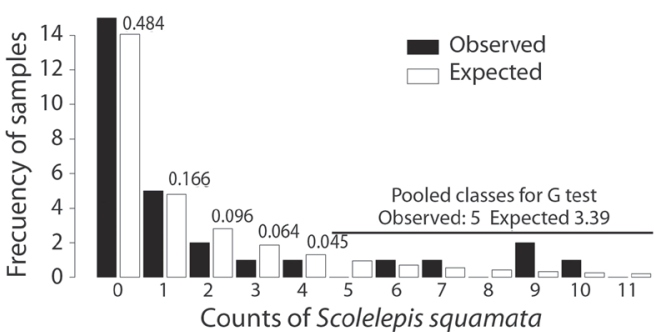

E

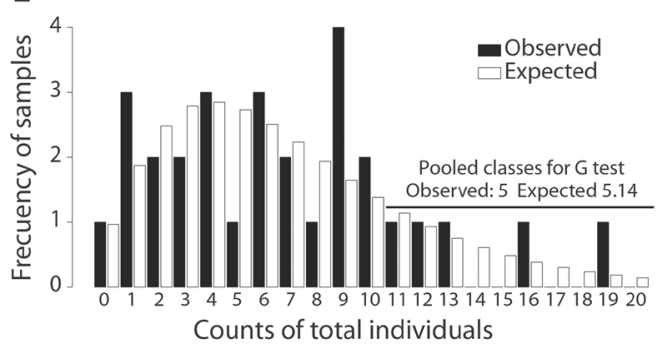

B

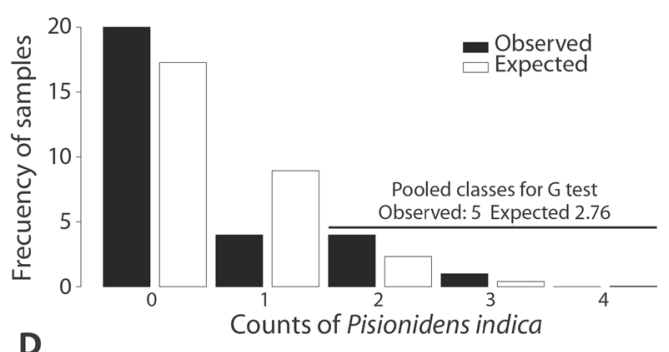

D

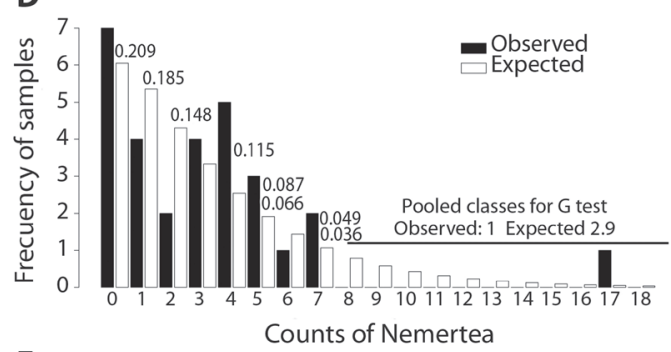

$\mathbf{F}$

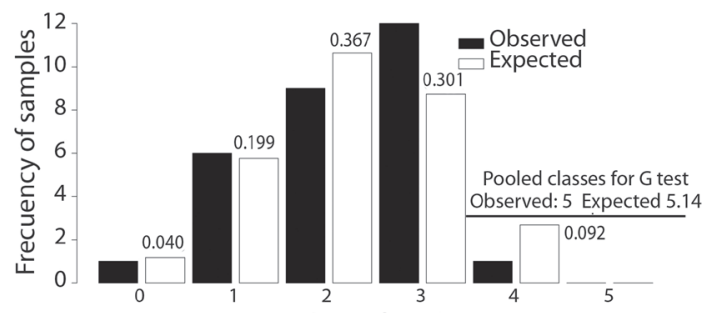

Counts of total taxa

Fig. 4. Observed and expected frequencies of samples by counts of individuals of A) Isopoda, B) Pisionidens indica, C) Scolelepis squamata D) Nemertea, E) Total fauna and F) counts of taxa number in Mondonguillo beach to low tide level. Costa Rica, September 2006. The probability of obtaining a count of $\mathrm{n}$ individuals is showed as number over the expected values for each taxon.

$\left.\chi^{2} \alpha(0.025)=44.46\right)$. The maximum number of individuals that may appear in a sampling unit (k) was 4 and the probability (p) of an event $x$ occurs for this data count was 0.552 . In this way, the count data of taxa number in this beach can be modeled by the binomial distribution (Fig. 4F; G test $=2.74$; d.f. $=2 ; \mathrm{p}=0.253$ ). The highest probability was to obtain a count of two or three taxa in a corer (Fig. 4F).

\section{DISCUSSION}

The Caribbean sandy beaches of Costa Rica and Panama are known to have low densities of intertidal fauna. The abundances (74
$\%$ ) of these beaches have been shown to be monopolized by only six taxa (Dexter, 1974). This is congruent with the scarce number of macrofaunal taxa and low abundance per core found in the present study. Species are not able to maintain higher populations in exposed beaches where wide areas of sediment are removed periodically by strong wave exposure (Defeo, \& McLachlan, 2005). Moreover, some studies have shown that the combine action of irregular tidal cycles, as well as intense hydrodynamics and low food in sediments and water could also explain the low macrofauna density found in this sandy exposed beach (Dexter, 1974; Alongi, 1990). 
The isopods found in the present study were previously reported by Dexter (1974) as Cirolana salvadorensis (Glynn, et al., 1975). Dexter (1974) indicated that this isopod occurred in $50 \%$ of the quadrants which is similar to their presence in Mondonguillo beach (17 of 29 corers). This species had the highest probability of being found in the intertidal zone $(\mathrm{p}=0.365$, Poisson distribution). Isopods are active swimmers during high tides and can bury to avoid being washed from the unstable sediments by tides and waves (Little, 2000). This species occurs in all types of sediments but reflected higher densities in sediments $>300 \mu \mathrm{m}$ (Dexter, 1974). The sediments in Mondonguillo were mainly $<250 \mu \mathrm{m}$ which could explain the observed random pattern along the beach. The other isopod A. brasiliensis was uncommon in most of the beaches sampled by Dexter (1974) as was seen in the present study.

Pisionidens indica was randomly distributed based upon the Index of Dispersion (ID) and does not fit a Poisson distribution. Hurlbert (1990) indicated that the Poisson distribution does not cover all possibilities of count patterns with an ID close to 1 . This worm was absent in a section of the beach but appeared in the zones where the bed of the beach was apparently removed by storms (sectors: 9-19, 43-49). Pisionidens indica is known to inhabit the dynamic surf zone of tropical beaches and is well adapted to burrowing in sands (McCarthy, Laws, Estabrooks, BaileyBrock, \& Kay, 2000; Jumars, Dorgan, \& Lindsay, 2015). This species can therefore avoid hard conditions at the sediment surface similarly to other interstitial species (Giere, 2013). Méndez-Ubach, Solis-Weiss, \& Carranza-Edwards (1985) indicated that this species does not select the grain size but prefers sediment stability, as in the fine sediments sections of Mondonguillo beach.

Sedentary animals are scarce on beaches of great dynamism (Little, 2000) and this was the case for Mondonguillo beach where $S$. squamata was the single surface feeder in the sediment. Barros, Borzone, \& Rosso (2001) showed that $S$. squamata prefers beaches with fine to very fine grain size (as Mondonguillo beach). On contrast, this worm was not found in sites where the slope begins abruptly close to the beach vegetation (sectors: 9-19, 43-49), possibly this worm was removed together with the sand of the beach. Moreover, Crawley (2007) indicated that low values $(<1)$ of negative-binomial exponent (k) showed high aggregation, as in the case of $S$. squamata $(\mathrm{k}$ $=0.413)$. This highly clumped pattern along the central zone of the beach can be a response to environmental favorable conditions as Rizzo \& Amaral (2001) consider members of the genus Scolelepis to be opportunists. In the present study $S$. squamata increased their abundance from the mouth of Pacuare river to the center of the beach when grain size fractions $>125$ $\mu \mathrm{m}$ increased.

Abundances of the small size nemertean species fit the negative binomial distribution. The value of negative-binomial exponent $(\mathrm{k})$ of 1.22 indicated an aggregated pattern but somewhat more dispersed than that of $S$. squamata. Clumps were determined mainly by changes in their abundance rather than by their presence or absence along the beach. Nemerteans were found attached to sand grains, a common behavior of meiofaunal organisms (Little, 2000; Giere, 2013). This strategy could avoid being removed by the surf and it explains their presence along the beach. Nemerteans are predators on meiofauna and the variations in density could be associated with changes of abundance of smaller meiofauna prey (Little, 2000; Giere, 2013).

The contribution of nemerteans and $S$. squamata to the total abundance produced a clumped pattern but show an aggregation exponent of 2.7 indicating greater dispersion by the randomly distributed taxa. In this way, the communities in this dynamic marine sediment represented a mosaic of different stages of colonization and succession producing patches of different taxa in space (Johnson, 1972; Gray \& Elliot, 2009). On the other hand, taxa richness followed a uniform pattern on the low tide level and it was lower than that of other beaches from Costa Rica (Dexter 1974). The 
carrying capacity in these unstable sediments was limited to a few opportunistic or taxa welladapted to mechanical disturbances (Defeo, \& McLachlan, 2005; Giere, 2013). Moreover, the different patterns of distribution among species in the same tide level could be associated with the distribution of food resources, niche partitioning, and adaptations or species competition. But Defeo, \& McLachlan (2005) point out that on exposed sandy beaches biological interactions are usually minimal. There are beach zones with low densities surely as a result of wave dynamics that remove wide sections of the sediment. Additionally, evidence of increase of most fine sediments in direction to river mouths can influence the distribution patterns observed. The patches of abundance within the beach could be related to morphologic changes that impose the influence of the strong surf. A study of temporal trends will be needed to test if spatial distribution for each taxon proposed here persists.

\section{ACKNOWLEDGMENTS}

I thank Rubén Venegas (Investigation Assistants Program of the Pacuare Reserve ) by guiding me in this work. Tomas Pacheco and Carlos Fernández of The Endangered Wildlife Trust for the facilities of transport, lodging, and permission to work in the area. Gerardo Umaña and José Vargas of CIMAR provided the laboratory facilities. Rita Vargas of Museo de Zoología, Universidad de Costa Rica, who identified isopods. Catalina Benavides (CIMAR) elaborated the map. I thank Harlan Dean for their review of the manuscript. This manuscript is part of the project of CIMAR \#808-B4-117.

\section{RESUMEN}

Distribución espacial de la macrofauna dentro de una playa arenosa de la costa Caribe de Costa Rica. Conocer el patrón espacial de los conteos de individuos en una población es básico para entender otros aspectos de su ecología. En el presente estudio, la fauna bentónica se muestreó en la marea baja de una playa arenosa en la Reserva Pacuare, costa Caribe, Costa Rica. Los datos de recuento de taxones encontrados en 29 núcleos se analizaron para determinar su distribución espacial. Se encontraron dos especies de poliquetos: La primera, Scolelepis (Scolelepis) squamata (O. F. Mueller, 1806) que fue común en el centro de la playa y que tuvo un patrón agregado. La segunda, Pisionidens indica (Aiyar \& Alikunhi, 1940) se encontró en baja densidad con un patrón de distribución aleatoria. Dos isópodos se encontraron tambien aleatoriamente: Excirolana braziliensis Richardson, 1912 estaba a lo largo de la playa, mientras que Ancinus brasiliensis Lemos de Castro, 1959 apareció solo en dos estaciones. Un nemertino meiofaunal pegado a los granos de arena fue el organismo más común en la zona intertidal, en un patrón agrupado. Los parches de abundancia dentro de la playa podrían deberse al cambio morfológico impuesto por la influencia del oleaje fuerte. Además, los diferentes patrones de distribución en el sedimento entre especies, en el mismo nivel de marea pueden ser el resultado de la distribución de los recursos alimenticios, distribución de nichos, o competencia entre las especies. La riqueza de taxones siguió un patrón uniforme y fue más baja que en otras playas de Costa Rica. La capacidad de carga en estos sedimentos inestables se limitó a pocos taxones oportunistas así como a los que están bien adaptados para soportar disturbios mecánicos.

Palabras clave: Fondo suave, Datos de conteos, Poliquetos, Peracarida, Poisson, Binomial negativa.

\section{REFERENCES}

Alongi, D. M. (1989). Ecology of tropical soft-bottom benthos: a review with emphasis on emerging concepts. Revista de Biología Tropical, 37, 85-100.

Alongi, D. M. (1990). The ecology of tropical soft-bottom benthic ecosystems. Oceanography and Marine Biology: An Annual Review, 28, 381-496.

Bakus, G. J. (1968). Zonation in marine gastropods of Costa Rica and species diversity. The Veliger, 10, 207-211.

Barros, F., Borzone, C. A., \& Rosso, S. (2001). Macroinfauna of six beaches near Guaratuba Bay, Southern Brazil. Brazilian Archives of Biology and Technology, 44(4), 351-364.

Crawley, M. J. (2007). The R book. Chichester: John Wiley \& Sons.

De la Cruz, E., \& Vargas, J. A. (1987). Abundancia y distribución vertical de la meiofauna en la playa fangosa de Punta Morales, Golfo de Nicoya, Costa Rica. Revista de Biología Tropical, 35, 363-367.

Defeo, O., \& Mclachlan, A. (2005). Patterns, processes and regulatory mechanisms in sandy beach macrofauna: a multi-scale analysis. Marine Ecology Progress Series, 295, 1-20. 
Dexter, D. M. (1974). Sandy beach fauna of the Pacific and Atlantic coast of Costa Rica and Colombia. Revista de Biología Tropical, 22, 51-66.

Dexter, D. M. (1979). Community structure and seasonal variation in intertidal Panamanian sandy beaches. Estuarine and Coastal Marine Science, 9(5), 543-558.

Dittmann, S., \& Vargas, J. A. (2001). Tropical tidal flat benthos compared between Australia and Central America. In K. Reise (Ed.), Ecological Comparisons of Sedimentary Shores, Ecological Studies 151 (pp. 275-293). Berlin, Germany: Springer.

Giere, O. (2013). Meiobenthology: the microscopic motile fauna of aquatic sediments. Berlin, Germany: Springer.

Glynn, P. W., Dexter, D. M., \& Bowman, T. E. (1975). Excirolana braziliensis, a Pan-American sand beach isopod: taxonomic status, zonation and distribution. Journal of Zoology, 175(4), 509-521.

Gonçalves, S. C., Anastácio, P. M., Pardal, M. A., Cardoso, P. G., Ferreira, S. M., \& Marques, J. C. (2009). Sandy beach macrofaunal communities on the western coast of Portugal - Is there a steady structure under similar exposed conditions? Estuarine, Coastal and Shelf Science, 81(4), 555-568.

Gray, J. S., \& Elliott, M. (2009). Ecology of marine sediments: from science to management. Oxford, United Kingdom: Oxford University Press.

Guzmán, H. M., Obando, V., \& Cortés, J. (1987). Meiofauna associated with a Pacific coral reef. In Costa Rica. Coral Reefs, 6, 107-112.

Hurlbert, S.H. (1990). Spatial Distribution of the Montane Unicorn. Oikos, 58, 257-271.

Johnson, R.G. (1972). Conceptual models of benthic marine communities. In T. J. M. Schopf (Ed.), Models in Paleobiology (pp. 148-159). California, USA: Freeman Cooper.

Jumars, P. A., Dorgan, K. M., \& Lindsay, S. M. (2015). Diet of Worms Emended: An Update of Polychaete Feeding Guilds Appendix, A Family-by-Family Review. Annual Review of Marine Science, 7, 497-520.

Krebs, C.J. (1999). Ecological Methodology (2 ed). California, USA: Addison-Wesley,
León, R., \& Vargas, J.A. (1998). Macroinfauna of a tropical fjord-like embayment, Golfo Dulce, Costa Rica. Revista de Biología Tropical, 46 (Suppl. 6), 63-79.

Little, C. (2000). The Biology of Soft Shores and Estuaries. Oxford, United Kingdom: Oxford University Press.

Maurer, D., \& Vargas, J. A. (1984). Diversity of softbottom benthos in a tropical estuary: Gulf of Nicoya, Costa Rica. Marine Biology, 81, 97-106.

Maurer, D., Vargas J. A., \& Dean. H. K. (1988). Polychaetous annelids from the Gulf of Nicoya, Costa Rica. Internationale Revue der gesamten Hydrobiologie und Hydrographie, 73(1), 43-59.

McCarthy, S. A., Laws, E. A., Estabrooks, W. A., Baileybrock, J. H., \& Kay, E. A. (2000). Intra-annual variability in Hawaiian shallow-water, soft-bottom macrobenthic communities adjacent to a eutrophic estuary. Estuarine, Coastal and Shelf Science, 50, 245-258.

Méndez-Ubach, M. N., Solis-Weiss, V., \& CarranzaEdwards, A. (1985). La importancia de la granulometría en la distribución de organismos bentónicos. estudio de playas del estado de Veracruz, México. Anales del Centro de Ciencias del Mar y Limnologia, Universidad Nacional Autónoma de México, 457, 45-56.

Nichols-Driscoll, J. (1976). Benthic invertebrate communities in Golfo Dulce, Costa Rica, an anoxic basin. Revista de Biología Tropical, 24, 281-297.

R Core Team (2014). $R$ : A language and environment for statistical computing. Vienna, Austria: R Foundation for Statistical Computing. Retrieved fromhttp:// www.R-project.org/.

Rizzo, A. E., \& Amaral, A. C. Z. (2001). Spatial distribution of annelids in the intertidal zone in Sao Sebastiao Channel, Brazil. Scientia Marina, 65, 323-331.

Rostad, T., \& Hansen, K. L. (2001). The effects of trawling on the benthic fauna of the Gulf of Nicoya, Costa Rica. Revista de Biología Tropical, 49 (Suppl. 2), 91-95.

Salazar, A., Lizano, O. G., \& Alfaro, E. J. (2004). Composición de sedimentos en las zonas costeras de Costa Rica utilizando Fluorecescencia de Rayos-X (FRX). Revista de Biología Tropical, 52 (Suppl. 2), 61-75. 
Sibaja-Cordero, J. A., Troncoso, J. S., Cortés, J., Moreira, J., Vargas, J. A., \& Benavides-Varela, C. (2016). Biodiversity and density of subtidal benthos of an oceanic tropical island (a comparison within the Pacific Ocean). Journal of Sea Research, 115, 47-58.

Vargas, J. A. (1987). The benthic community of an intertidal mud flat in the Gulf of Nicoya, Costa Rica. Description of the community. Revista de Biologia Tropical, 35, 229-316.

Vargas, J. A. (1988a). A survey of the meiofauna of an eastern tropical Pacific intertidal mud flat. Revista de Biología Tropical, 36, 541-544.
Vargas, J. A. (1988b). Community structure of macrobenthos and the results of macrodepredator exclusion on a tropical mud flat. Revista de Biología Tropical, 36, 287-308.

Vargas-Zamora, J. A., Sibaja-Cordero, J. A., Dean, H. K., \& Solano-Ulate, S. (2015). Abundance patterns (19841987 / 1994-1998) of polychaete worms (Annelida) from an estuarine tidal flat, Pacific, Costa Rica. Cuadernos de Investigación UNED, 7(2), 233-248.

Thrush, S. F. (1991). Spatial patterns in soft-bottom communities. Trends in Ecology and Evolution, 6, 75-79.

See Digital Appendix at: / Ver Apéndice digital en: https://revistas.ucr.ac.cr/index.php/rbt 